$\underline{\text { USGS Woods Hole Science Center } \quad \text { Coastal and Marine Program }}$

\title{
Coastal Vulnerability Assessment of Olympic National Park to Sea-Level Rise
}

Elizabeth A. Pendleton, Erika S. Hammar-Klose, E. Robert Thieler, S. Jeffress Williams

U.S. Geological Survey Open-File Report 04-1021, Electronic Book

2004

For Additional Information:

See the National Park Unit Coastal Vulnerability study at http://woodshole.er.usgs.gov/projectpages/nps-cvi/,

the National Coastal Vulnerability study at http://woodshole.er.usgs.gov/project-pages/cvi/, or view the USGS online fact sheet for this project in PDF format at http://pubs.usgs.gov/fs/fs095021.

To visit Olympic National Park go to http://www.nps.gov/olym/index.htm.

Contact:

Elizabeth A. Pendleton, Erika S. Hammar-Klose, E. Robert Thieler, and S. Jeffress Williams U.S. Geological Survey 384 Woods Hole Road Woods Hole, MA 02543

E-mail: ependleton@usgs.gov, ehammark@usgs.gov, rthieler@usgs.gov, jwilliams@usgs.gov, Telephone: $508-457-2259$ or 508-548-8700

Rebecca Beavers

National Park Service

Natural Resource Program Center

Geologic Resources Division

P.O. Box 25287

Denver, CO 80225-0287 
E-mail: Rebecca_Beavers@nps.gov

Telephone: 303-987-6945

\section{ABSTRACT}

A coastal vulnerability index (CVI) was used to map the relative vulnerability of the coast to future sea-level rise within Olympic National Park (OLYM), Washington. The CVI scores the following in terms of their physical contribution to sea-level riserelated coastal change: geomorphology, regional coastal slope, rate of relative sealevel rise, shoreline change rates, mean tidal range and mean wave height. The rankings for each variable were combined and an index value calculated for 1-minute grid cells covering the park. The CVI highlights those regions where the physical effects of sea-level rise might be the greatest. This approach combines the coastal system's susceptibility to change with its natural ability to adapt to changing environmental conditions, yielding a quantitative, although relative, measure of the park's natural vulnerability to the effects of sea-level rise. The CVI provides an objective technique for evaluation and long-term planning by scientists and park managers. The Olympic National Park coast consists of rocky headlands, pocket beaches, glacial-fluvial features, and sand and gravel beaches. The Olympic coastline that is most vulnerable to sea-level rise are beaches in gently sloping areas.

\section{INTRODUCTION}

The National Park Service (NPS) is responsible for managing nearly $12,000 \mathrm{~km}$ (7,500 miles) of shoreline along oceans and lakes. In 2001, the U.S. Geological Survey (USGS), in partnership with the NPS Geologic Resources Division, began conducting hazard assessments of future sea-level change by creating maps to assist NPS in managing its valuable coastal resources. This report presents the results of a vulnerability assessment for Olympic National Park (OLYM), highlighting areas that are likely to be most affected by future sea-level rise.

Global sea level has risen approximately 18 centimeters ( 7.1 inches) in the past 
century (Douglas, 1997). Climate models predict an additional rise of $48 \mathrm{~cm}$ (18.9 in.) by 2100 (IPCC, 2002), which is more than double the rate of rise for the 20th century. Potential coastal impacts of sea-level rise include shoreline erosion, saltwater intrusion into groundwater aquifers, inundation of wetlands and estuaries, and threats to cultural and historic resources as well as infrastructure. Predicted accelerated global sea-level rise has generated a need in coastal geology to determine the response of a coastline to sea-level rise. However, an accurate and quantitative approach to predicting coastal change is difficult to establish. Even the kinds of data necessary to make shoreline response predictions are the subject of scientific debate. A number of predictive approaches have been proposed (National Research Council, 1990), including: 1) extrapolation of historical data (e.g., coastal erosion rates), 2) static inundation modeling, 3) application of a simple geometric model (e.g., the Bruun Rule), 4) application of a sediment dynamics/budget model, or 5) Monte Carlo (probabilistic) simulation based on parameterized physical forcing variables. However, each of these approaches has inadequacies or can be invalid for certain applications (National Research Council, 1990). Additionally, shoreline response to sea-level change is further complicated by human modification of the natural coast such as beach nourishment projects, and engineered structures such as seawalls, revetments, groins, and jetties. Understanding how a natural or modified coast will respond to sea-level change is essential to preserving vulnerable coastal resources.

The primary challenge in predicting shoreline response to sea-level rise is quantifying the important variables that contribute to coastal evolution in a given area. In order to address the multi-faceted task of predicting sea-level rise impact, the USGS has implemented a methodology to identify areas that may be most vulnerable to future sea-level rise (see Hammar-Klose and Thieler, 2001). In this application, different ranges of vulnerability (low to very high) describe a coast's susceptibility to physical change as sea level rises. This technique focuses on six variables which strongly influence coastal evolution:

1) Geomorphology

2) Histroical shoreline change rate

3) Regional coastal slope 
4) Relative sea-level change

5) Mean significant wave height

6) Mean tidal range

These variables can be divided into two groups: 1) geologic variables and 2) physical process variables. The geologic variables are geomorphology, historic shoreline change rate, and coastal slope; they account for a shoreline's relative resistance to erosion, long-term erosion/accretion trend, and its susceptibility to flooding, respectively. The physical process variables include significant wave height, tidal range, and sea-level change, all of which contribute to the inundation hazards of a particular section of coastline over time scales from hours to centuries. A relatively simple vulnerability ranking system (Table 1) allows the six variables to be incorporated into an equation that produces a coastal vulnerability index (CVI). The CVI can be used by scientists and park managers to evaluate the likelihood that physical change may occur along a shoreline as sea level continues to rise. Additionally, NPS staff will be able to incorporate information provided by this vulnerability assessment technique into general management plans.

\section{DATA RANKING}

Table 1 shows the six variables described in the Introduction, which include both quantitative and qualitative information. Actual variable values are assigned a vulnerability ranking based on value ranges, whereas the non-numerical geomorphology variable is ranked qualitatively according to the relative resistance of a given landform to erosion. Shorelines with erosion/accretion rates between -1.0 and $+1.0 \mathrm{~m} / \mathrm{yr}$ are ranked as moderately vulnerable with increasingly higher rates of erosion or accretion given correspondingly higher or lower vulnerability rankings. Regional coastal slopes range from very high vulnerability, $<4.56$ percent to very low vulnerability at values $>14.7$ percent. The rate of relative sea-level change is ranked using the modern rate of eustatic rise $(1.8 \mathrm{~mm} / \mathrm{yr})$ as very low vulnerability. Since this is a global or "background" rate common to all shorelines, the sea-level rise ranking reflects primarily local to regional isostatic or tectonic adjustment. Mean 
wave height rankings range from very low $(<1.1 \mathrm{~m})$ to very high $(>2.6 \mathrm{~m})$. Tidal range is ranked such that microtidal $(<1 \mathrm{~m})$ coasts have very high vulnerability and macrotidal (>6 m) coasts have very low vulnerability.

\section{OLYMPIC NATIONAL PARK}

The rugged landscape of Olympic National Park (Figure 1) is a result of the subduction of the Juan de Fuca oceanic plate below the North American plate beginning about 35 million years ago. The mountains within Olympic National Park are geologically very young, and as a consequence the surrounding landscape is young and varies widely in morphology. Large ice sheets during Pleistocene glaciations (2 million - 13,000 years ago) further modified the geomorphology of the park by carving deep U-shaped valleys dipping toward a sediment-starved collision coast. The park shoreline is over $100 \mathrm{~km}$ ( 65 miles) of primarily rocky and cliffed coast with intermittent sand or gravel pocket beaches. Approximately $95 \%$ of the park is designated as wilderness making it a very beautiful and pristine shore. Seaward of the Olympic shoreline lies the Olympic Coast National Marine Sanctuary administered by the National Oceanic and Atmospheric Administration.

In addition to the coastal impacts associated with predicted sea-level rise, Olympic is also susceptible to tsunamis generated both locally and distant. The presence of the subduction zone a few hundred miles offshore poses a constant threat to earthquakegenerated tsunamis. The Northwest Washington coast is also periodically impacted with increased storminess, shoreline erosion, large wind driven waves, and elevated sea levels associated with El Niño events (Komar, 1997).

\section{METHODOLOGY}

Data for each of the six variables mentioned above were gathered from state and federal agencies to develop a database for a park-wide assessment of coastal vulnerability (Table 2). The database is based on that used by Thieler and HammarKlose (1999) and loosely follows an earlier database developed by Gornitz and White 
(1992). A comparable assessment of the sensitivity of the Canadian coast to sealevel rise is presented by Shaw and others (1998). The database was constructed using a 1:70,000-scale shoreline for the Olympic Peninsula that was produced from the medium resolution digital vector U.S. shoreline provided by the Strategic Environmental Assessments (SEA) Division of NOAA's Office of Ocean Resources Conservation and Assessment (ORCA)

(http://spo.nos.gov/project/shoreline/shoreline.html). Data for each of the six variables (geomorphology, shoreline change, coastal slope, relative sea-level rise, significant wave height, and tidal range) were added to the shoreline attribute table using a 1minute (approximately $1.5 \mathrm{~km}$ ) grid (Figure 2). Next the data were assigned a relative vulnerability value from 1-5 (1 is very low vulnerability, 5 is very high vulnerability) based on the potential magnitude of its contribution to physical changes on the coast as sea level rises (Table1).

\section{GEOLOGIC VARIABLES}

The geomorphology variable expresses the relative erodibility of different landform types (Table 1). The geomorphology of the Olympic coast varies from sandy beaches (5 - very high vulnerability) to rocky cliffs (1 - very low vulnerability) (Figure 3 - 10). These data were derived primarily from the Washington Department of Ecology database of shoreline aerial photos, (http://www.ecy.wa.gov/apps/shorephotos/) and were supplemented with data from USGS 1:250,000-scale topographic maps, the Cascadia beach - shoreline database, Pacific Northwest region (Peterson and others, 1994), and with the book, The Pacific Northwest Coast: Living with the shores of Oregon and Washington (Komar, 1997). In addition, field visits were made within the park to ground-truth the geomorphologic classification.

Historical shoreline change data for the ocean coast of Washington State were provided by the Coastal Monitoring and Analysis Program, Washington Department of Ecology, Olympia, Washington (R. C. Daniels, oral pers. comm., 2000). These longterm annual erosion rates for the ocean coast are derived from NOS T-Sheets for the years 1926 - 30 and orthophotoquads for the years 1994 - 96; rates for the bays are 
derived from NOS T-Sheets from 1950 and orthophotoquads for the years 1994 - 96. Shoreline-change rates for the Olympic coast all fall within 1 meter of erosion or accretion for the 1 minute cells generated here.

The determination of regional coastal slope identifies the relative vulnerability of inundation and the potential rapidity of shoreline retreat because low-sloping coastal regions should retreat faster than steeper regions (Pilkey and Davis, 1987). The regional slope of the coastal zone was calculated from a grid of topographic and bathymetric elevations extending landward and seaward of the shoreline. For Olympic National Park, elevation data were obtained from the National Geophysical Data Center (NGDC) as gridded topographic and bathymetric elevations for 90-meter grid cells. Coastal slope was calculated for a 10-km (6.2 mile) radius (landward and seaward of the barrier) and then resampled to 1-minute resolution (Figure 2). The regional coastal slope for Olympic ranged from very high vulnerability $(<4.55 \%)$ to moderate vulnerability $(7.75-10.85 \%)$ (Figure $11 \mathrm{~A}-\mathrm{C})$.

\section{PHYSICAL PROCESS VARIABLES}

The relative sea-level change variable is derived from the increase or decrease in annual mean water elevation over time as measured at tide gauge stations along the coast. The rate of sea-level rise at Neah Bay and Astoria were used for Olympic National Park (Zervas, 2001). Water level records from Toke Point in Willapa Bay were not used because the record is less than 50 years and the sea-level rise signal is likely affected by events such as EI Niño. The sea-level rise variable inherently includes both global sea-level rise as well as regional sea-level rise due to isostatic and tectonic adjustments. Relative sea-level change data are a historical record, and thus only portray the recent sea-level trend ( $<150$ years). The rate of relative sealevel change within Olympic is very low $(<1.8 \mathrm{~mm} / \mathrm{yr})$

Mean significant wave height is used here as a proxy for wave energy which drives 
the coastal sediment budget. Wave energy is directly related to the square of wave height;

\section{$E=1 / 8 \rho g H^{2}$}

where $E$ is energy density, $H$ is wave height, $\rho$ is water density and $g$ is acceleration due to gravity. Thus, the ability to mobilize and transport beach material is a function of wave height squared. In this report, we use hindcast nearshore mean significant wave height data for the period 1976-95 obtained from the U.S. Army Corps of Engineers Wave Information Study (WIS) (Hubertz and others, 1996). The model wave heights were compared to historical measured wave height data obtained from the NOAA National Data Buoy Center to ensure that model values were representative of the study area. For Olympic National Park mean significant wave heights range from moderate $(2.0-2.25 \mathrm{~m})$ to high vulnerability $(2.25-2.60 \mathrm{~m})$.

Tidal range is linked to both permanent and episodic inundation hazards. Tide range data were obtained from the National Ocean Service (NOS) for two ocean tide stations near Olympic National Park; the values were contoured along the park shoreline and mapped to the 1-minute grid cells. All of Olympic has a tide range between 2 and 4 meters suggesting moderate vulnerability.

\section{THE COASTAL VULNERABILITY INDEX}

The coastal vulnerability index $(\mathrm{CVI})$ presented here is the same as that used in Thieler and Hammar-Klose (1999) and is similar to that used in Gornitz and others (1994), as well as to the sensitivity index employed by Shaw and others (1998). The $\mathrm{CVI}$ allows the six variables to be related in a quantifiable manner that expresses the relative vulnerability of the coast to physical changes due to future sea-level rise. This method yields numerical data that cannot be equated directly with particular physical effects. It does, however, highlight areas where the various effects of sea-level rise may be the greatest. Once each section of coastline is assigned a vulnerability value for each specific data variable, the coastal vulnerability index (CVI) is calculated as the square root of the product of the ranked variables divided by the total number of 
variables;

$\mathrm{CVI}=\sqrt{\frac{\left(a^{*} b^{*} c^{*} d^{*} e^{*} f\right)}{6}}$

where, $a$ = geomorphology, $b=$ shoreline erosion/accretion rate, $c=$ coastal slope,$d$ $=$ relative sea-level rise rate, $e=$ mean significant wave height, and $f=$ mean tide range. The calculated $\mathrm{CVI}$ value is divided into quartile ranges to highlight different vulnerabilities within the park. The CVI ranges (low - very high) reported here apply specifically to Olympic National Park, and are not comparable to CVI ranges in other parks where the CVI has been employed (i.e. very high vulnerability means the same among park units; it's the numeric values that differ, such that a numeric value that is very high vulnerability in one park may be moderate vulnerability in another). To compare vulnerability between coastal parks, the national-scale studies should be used (Thieler and Hammar-Klose, 1999, 2000a, and 2000b). We feel this approach best describes and highlights the vulnerability specific to each park.

\section{RESULTS}

The calculated CVI values for Olympic National Park range from $4.24-12.25$. The mean CVI value is 8.23; the mode is 10.95 ; and the median is 8.49 . The standard deviation is 1.1 . The 25 th, 50 th, and 75 th percentiles are $6.5,8.0$, and 9.5 , respectively.

Figure 12 shows a map of the coastal vulnerability index for the Olympic National Park. The CVI scores are divided into low, moderate, high, and very high-vulnerability categories based on the quartile ranges and visual inspection of the data. CVI values below 6.5 are assigned to the low vulnerability category. Values from $6.5-8.0$ are considered moderate vulnerability. High-vulnerability values lie between 8.01 and 9.5. CVI values above 9.5 are classified as very high vulnerability. Figure 13 shows a histogram of the percentage of Olympic National Park shoreline in each vulnerability category. A total of $55 \mathrm{~km}$ (32 miles) of shoreline is evaluated along the national 
seashore. Of this total, 30 percent of the mapped shoreline is classified as being at very high vulnerability due to future sea-level rise. Twenty-four percent is classified as high vulnerability, 22 percent as moderate vulnerability, and 24 percent as low vulnerability.

\section{DISCUSSION}

The data within the coastal vulnerability index (CVI) show variability at several spatial scales. However, the physical process variables maintain the most consistency over the extent of the park. The vulnerability of relative sea-level rise is very low over the length of the shoreline. The wave data are essentially high for the entire park except for two embayments south of Rialto Beach where wave heights are moderate because headlands provide a measure of protection from the dominant northwesterly winds. Tidal range vulnerability is moderate throughout the park.

The geologic variables show the most variability and thus have the most influence on the relative coastal vulnerability. Geomorphology in the park includes very low vulnerability rocky cliffs, very high vulnerability sandy beaches, as well as intermediate vulnerability landform types. Shoreline position within the park is stable with all erosion/accretions rates falling between $-1-+1$ meter per year making the entire Olympic shoreline moderately vulnerable with respect to shoreline change. Regional coastal slope varies from moderate vulnerability in small areas in the southern portion of the park to high vulnerability near Shi Shi Beach and Ruby Beach to very high vulnerability in the central portion of the park from north of Ozette Lake to south of Rialto Beach (Figure 12). The single most influential variable in the CVI is geomorphology; therefore it can be considered the dominant factor controlling how the Olympic shoreline will evolve as sea level rises. The geomorphology variable controls CVI changes on small spatial scales $(\sim 5 \mathrm{~km})$. However, variability within the coastal slope and significant wave height variables provide a larger-scale control (25$30 \mathrm{~km}$ ) on the CVI value. This results in an overall higher vulnerability shoreline within the central and northern portion of the park. 
Some park resources could be threatened with the likelihood of accelerated sea-level rise. A few examples of cultural resources that could be impacted within Olympic National Park include petroglyphs carved into rocks along the shore, shell middens, and Kalaloch Lodge (Figure 14). With the exception of the petroglyphs, the cultural resources mentioned here are located within regions that have been classified as very high vulnerability.

\section{CONCLUSIONS}

The coastal vulnerability index $(\mathrm{CVI})$ provides insight into the relative potential of coastal change due to future sea-level rise. The maps and data presented here can be viewed in at least two ways:

1) to show where physical changes are most likely to occur as sea-level rises; and

2) as a planning tool for Olympic National Park.

As ranked in this study, geomorphology is the most important variable in determining the CVI for Olympic. However, regional coastal slope and significant wave height produce regional scale variations in the coastal vulnerability index. Olympic National Park preserves a dynamic natural environment that must be understood in order to be managed properly. The $\mathrm{CVI}$ is one way that a park can assess objectively the natural factors that contribute to the evolution of the coastal zone, and thus how the park may evolve in the future. 


\section{REFERENCES}

Douglas, B.C., 1997, Global sea rise, a redetermination: Surveys in Geophysics, v. 18 , p. $279-292$.

Gornitz, V. and White, T.W., 1992, A coastal hazards database for the U.S. West Coast; ORNL/CDIAC-81, NDP-043C: Oak Ridge National Laboratory, Oak Ridge, Tennessee.

Gornitz, V.M., Daniels, R.C., White, T.W., and Birdwell, K.R., 1994, The development of a coastal vulnerability assessment database; vulnerability to sealevel rise in the U.S. southeast: Journal of Coastal Research, Special Issue No. 12, p. 327-338.

Hammar-Klose, E.S., and Thieler, E.R., 2001, Coastal vulnerability to sea-level rise; a preliminary database for the U.S. Atlantic, Pacific, and Gulf of Mexico coasts: U.S. Geological Survey, Digital Data Series, DDS-68, 1 CD.

Hubertz, J.M., Thompson, E.F., and Wang, H.V., 1996, Wave information studies of U.S. coastlines: Annotated bibliography on coastal and ocean data assimilation, U.S. Army Engineer Waterways Experiment Station, WIS Report 36, Vicksburg, 31 p.

IPCC, 2002, Climate change 2001, the scientific basis: Contribution of Working Group I to the Third Assessment Report of the Intergovernmental Panel on Climate Change, IPCC, , Geneva, Switzerland, 563 p. (Also available on the web at www.ipcc.ch)

Komar, P., 1997, The Pacific northwest coast: Living with the Shores of Oregon and Washington, Durham, Duke University Press, 196 p.

National Research Council, 1990, Managing coastal erosion, Washington: National Academy Press, $163 \mathrm{p}$. 
National Research Council, 1995, Beach nourishment and protection: Washington: National Academy Press, 334 p.

Peterson, C.D., Darienzo, M.E., Hamilton, D., Pettit, D., Yeager, R.K., Jackson, P.L., Rosenfeld, C.L., and Terich, T.T., 1994, Cascadia beach-shoreline database, Pacific northwest region, USA: State of Oregon, Department of Geology and Mineral Industries, Open-File Report 0-94-2.

Pilkey, O.H., and Davis, T.W., 1987, An analysis of coastal recession models, North Carolina coast, in Nummedal, D., Pilkey, D.H., and Howard, J.D., eds., Sea-level Fluctuation and Coastal Evolution: SEPM (Society for Sedimentary Geology) Special Publications No. 41, Tulsa, Oklahoma, p. 59-68.

Shaw, J., Taylor, R.B., Forbes, D.L., Ruz, M.H., and Solomon, S., 1998, Sensitivity of the Canadian coast to sea-level rise: Geological Survey of Canada Bulletin 505, $114 \mathrm{p}$.

Thieler, E.R., and Hammar-Klose, E.S., 1999, National assessment of coastal vulnerability to sea-level rise, U.S. Atlantic coast: U.S. Geological Survey, Open-File Report 99-593, 1 sheet. Online

Thieler, E.R., and Hammar-Klose, E.S., 2000a, National assessment of coastal vulnerability to sea-level rise, U.S. Pacific coast: U.S. Geological Survey, Open-File Report 00-178, 1 sheet. Online

Thieler, E.R., and Hammar-Klose, E.S., 2000b, National assessment of coastal vulnerability to sea-level rise, U.S. Gulf of Mexico coast: U.S. Geological Survey, Open-File Report 00-179, 1 sheet. Online

Zervas, C., 2001, Sea level variations of the United States 1854-1999: NOAA Technical Report NOS CO-OPS 36, 201 p. 


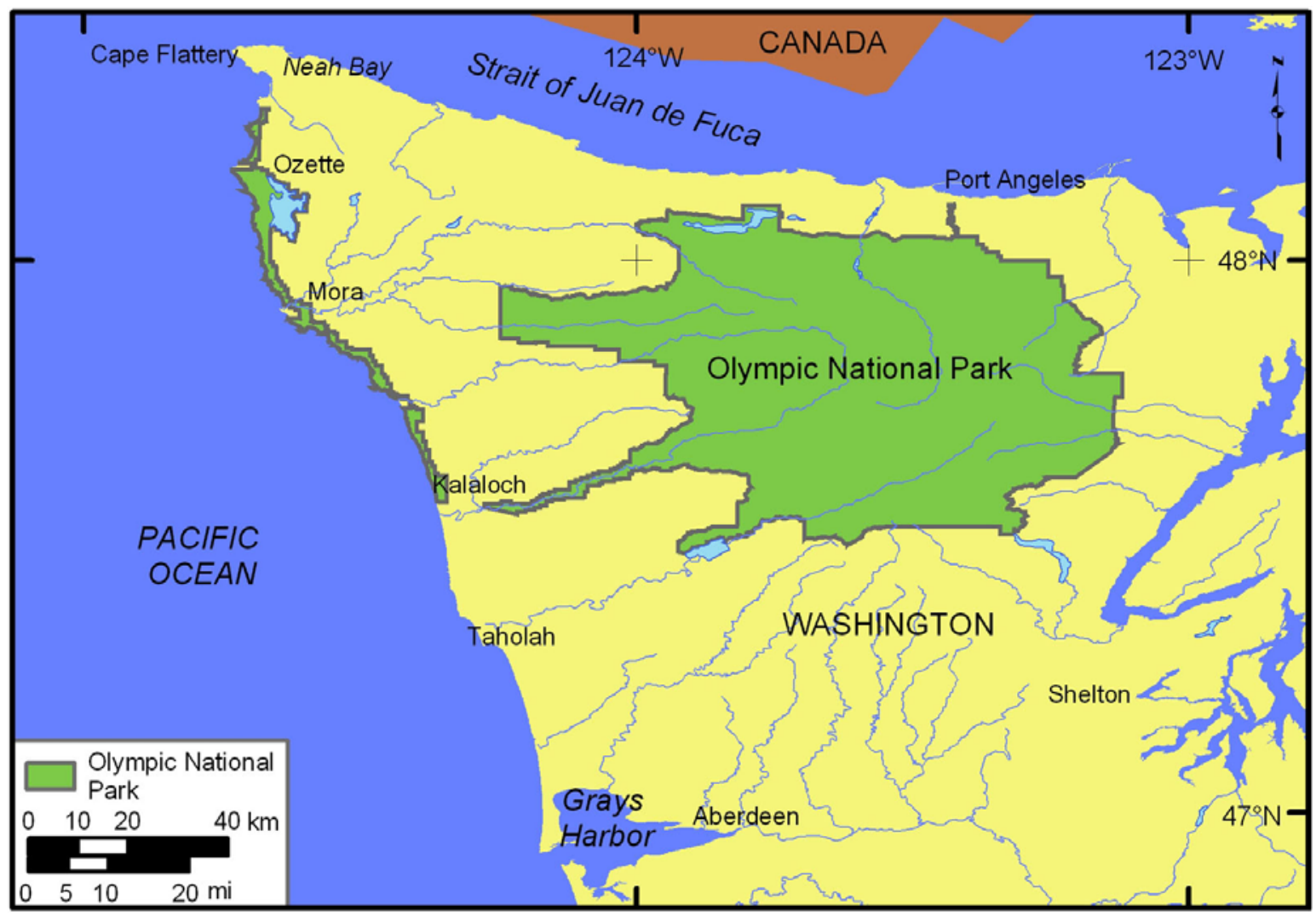

Figure 1. Location of Olympic National Park in Northwest Washington. 


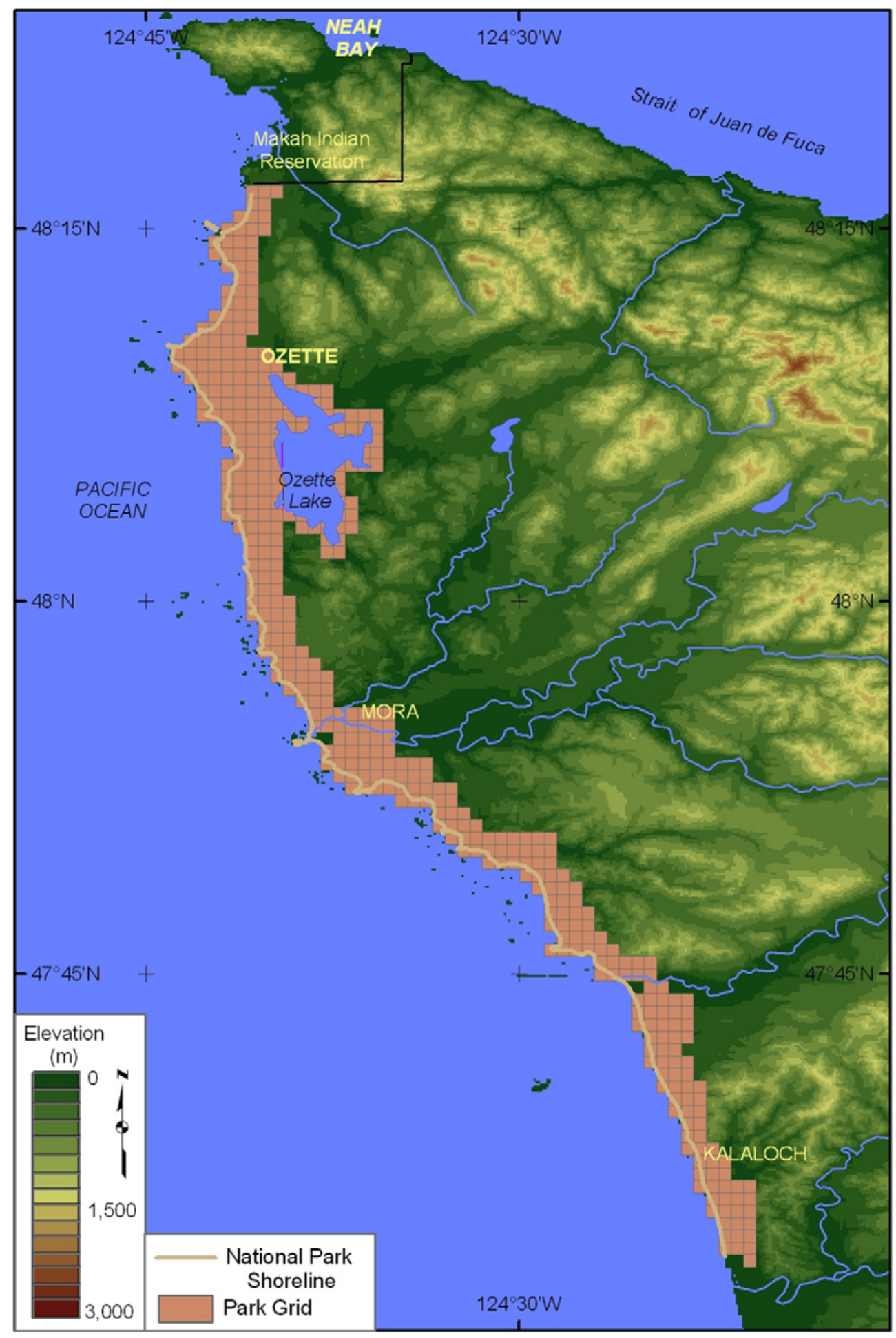

Figure 2. Shoreline grid for Olympic National Park. 


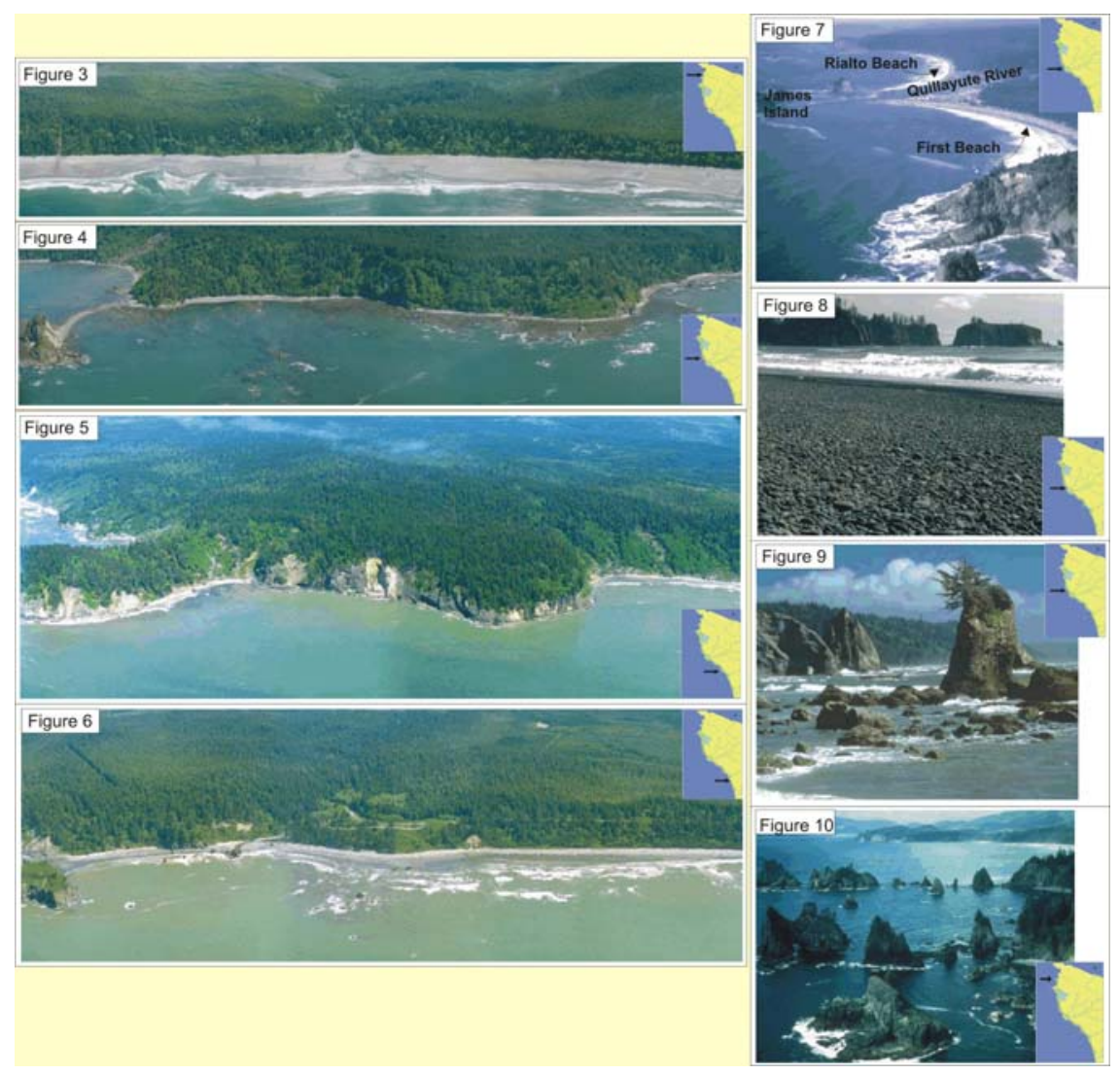

Figure 3: Shi Shi Beach in the north end of the park is classified as very high vulnerability. Washington Dept. of Ecology Photo.

Figure 4: Area north of Rialto Beach where geomorphology transitions from moderate to low vulnerability. Washington Dept. of Ecology Photo.

Figure 5: Hoh Head north of Hoh Indian Reservation is a rocky cliff at very low vulnerability. Washington Dept. of Ecology Photo.

Figure 6: Ruby Beach near Kalaloch is a gravel beach and considered high vulnerability. Washington Dept. of Ecology Photo.

Figure 7: Shore parallel oblique view showing the diverse geomorphology, including river mouths, pocket beaches, and rocky headlands. NPS photo.

Figure 8: Rialto Beach near the Quileute Reservation is a cobble beach (high vulnerability). NPS photo.

Figure 9: Hole in the Wall north of Rialto Beach (low vulnerability). NPS photo.

Figure 10: Point of Arches (very low vulnerability). NPS photo. 


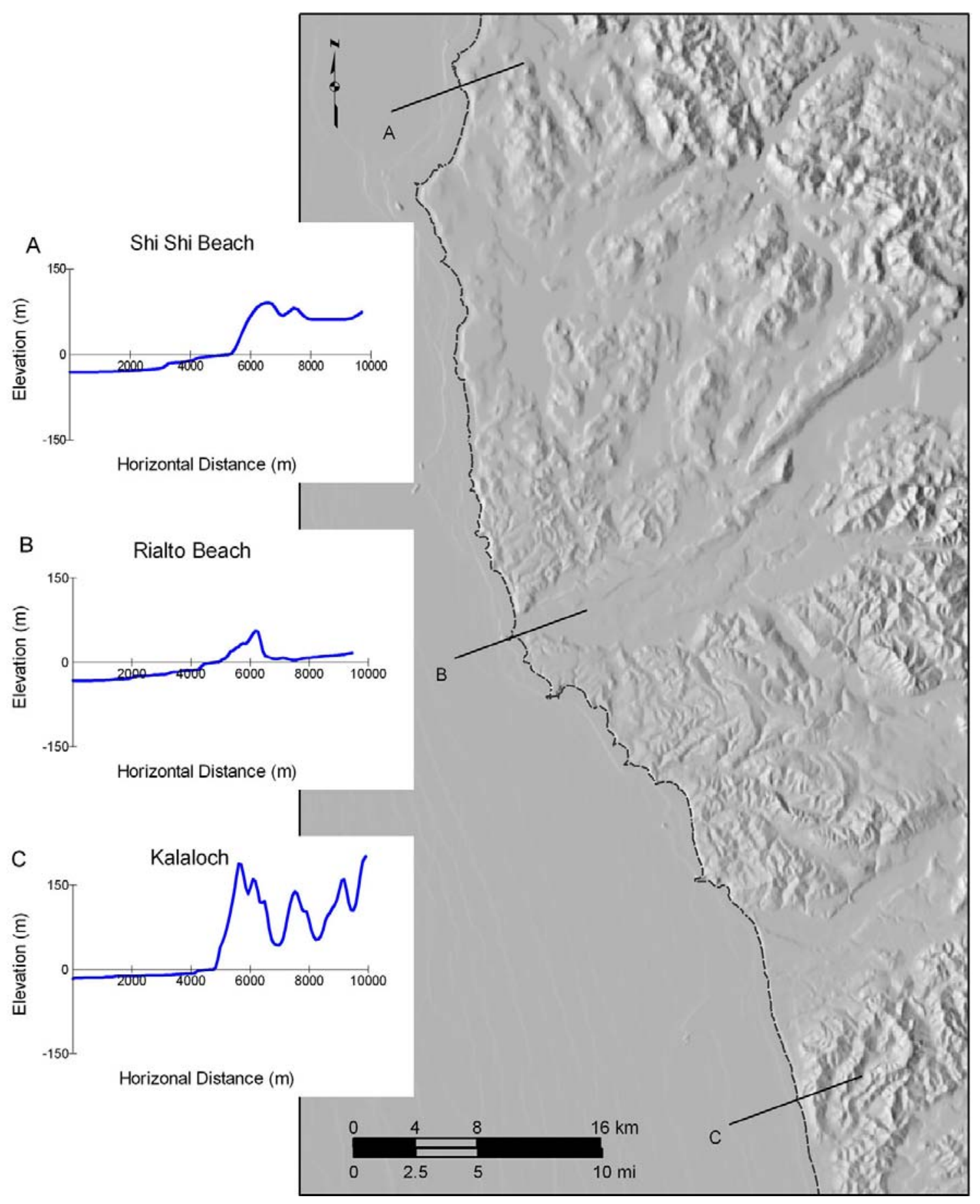

Figure 11. Regional coastal slope cross-sections for A) Shi Shi Beach (4 - high vulnerability) B) Rialto Beach (5 - very high vulnerability) and C) Kalaloch (3 - moderate vulnerability). 


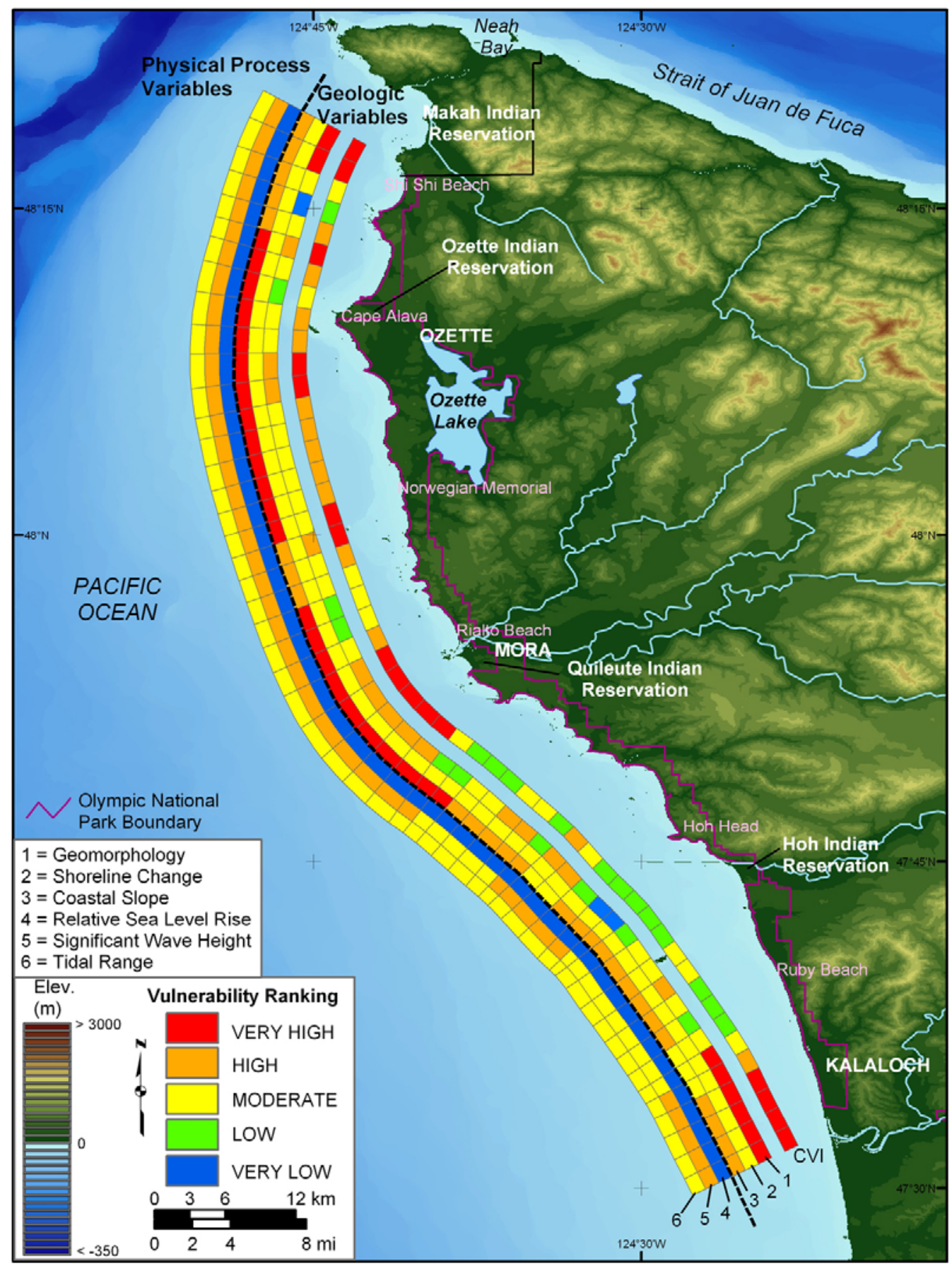

Figure 12. Relative Coastal Vulnerability for Olympic National Park. The innermost color bar is the relative coastal vulnerability index $(\underline{\mathrm{CVI}})$. The remaining color bars are separated into the geologic variables (1-3) and physical process variables (4 - 6). The very high vulnerability shoreline is generally located along sandy and gravel beaches where regional coastal slope is low. High vulnerability shoreline is concentrated north of Mora. Moderate vulnerability and low vulnerability coastline is mostly south of Mora. 


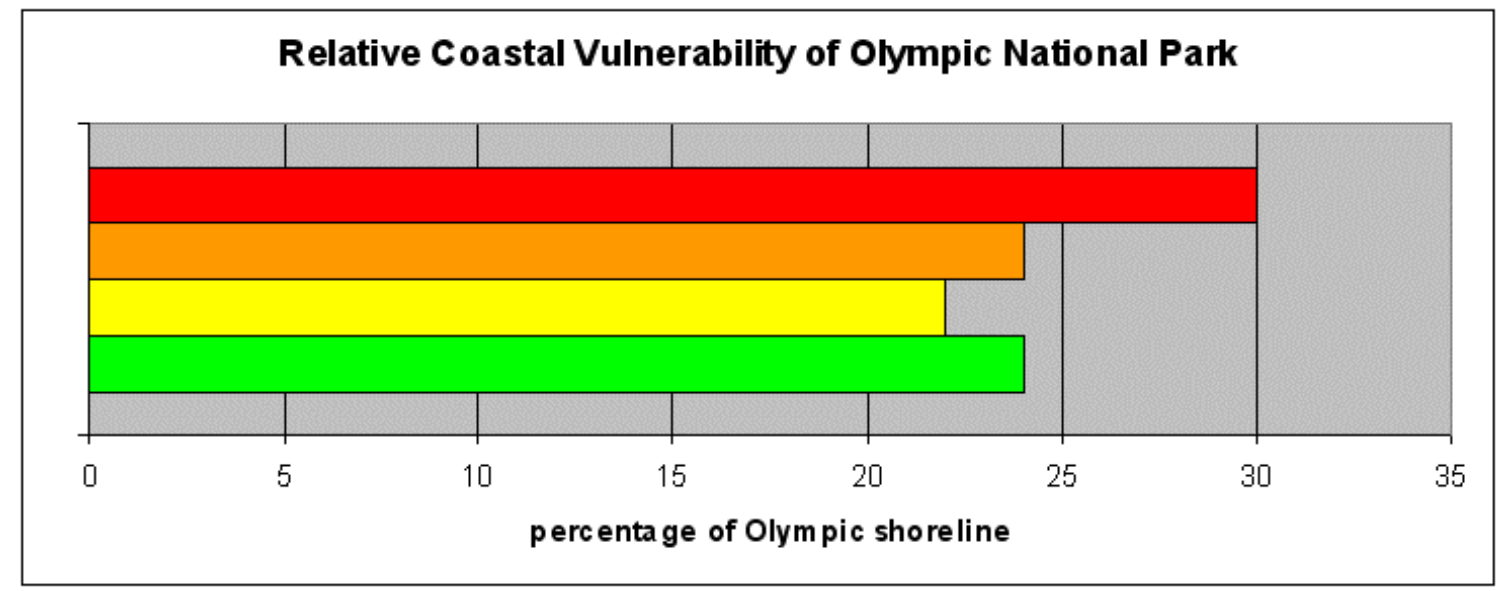

Figure 13. Percentage of Olympic National Park shoreline in each $\underline{\mathrm{CVI}}$ vulnerability category. 


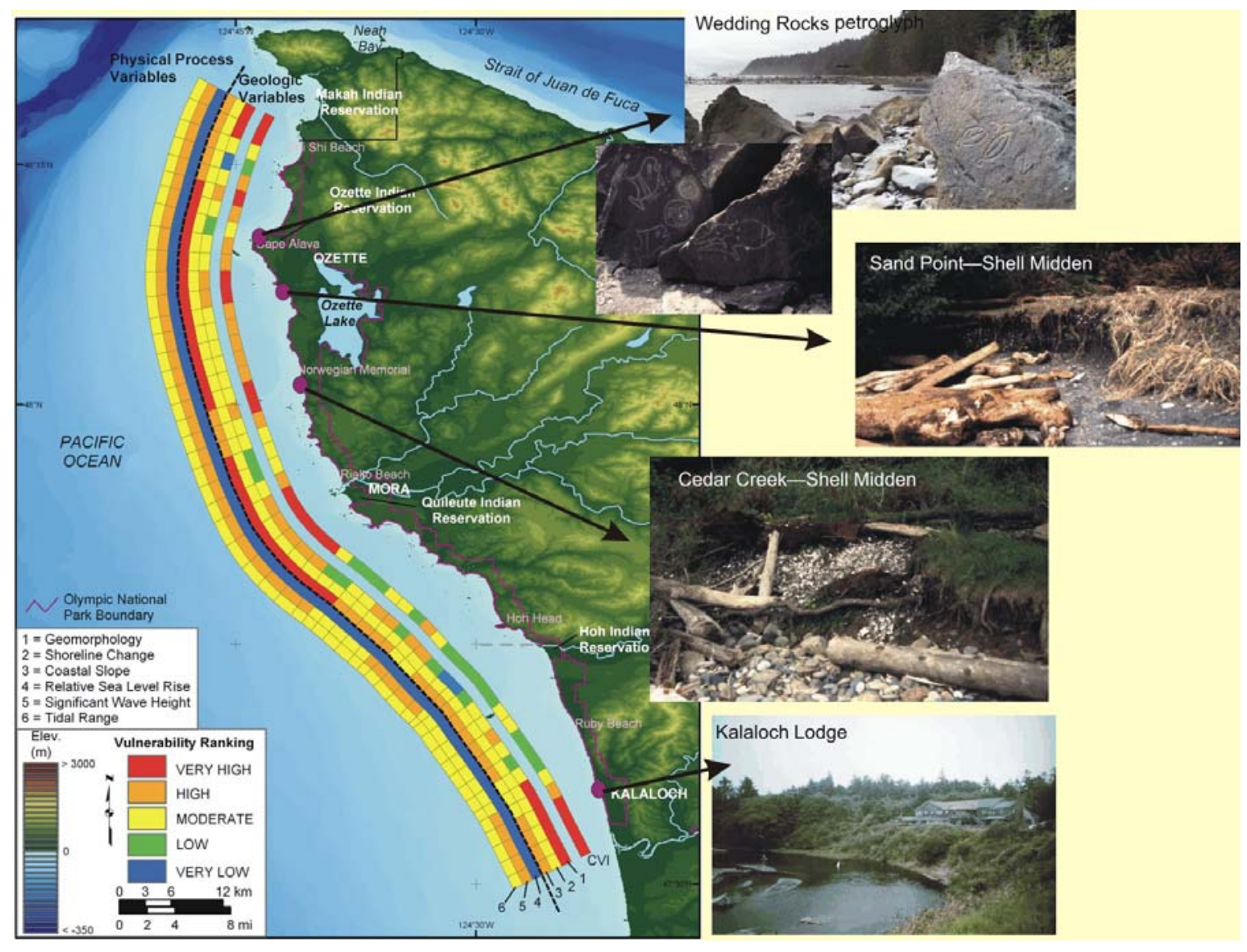

Figure 14. Location of selected cultural resources along the Olympic coast that may be affected by sea-level rise. 
Table 1: Ranges for Vulnerability Ranking of Variables on the Pacific Coast.

\begin{tabular}{|c|c|c|c|c|c|}
\hline Variables & $\begin{array}{c}\text { Very Low } \\
1\end{array}$ & $\begin{array}{c}\text { Low } \\
2\end{array}$ & $\begin{array}{c}\text { Moderate } \\
3\end{array}$ & $\begin{array}{c}\text { High } \\
4\end{array}$ & $\begin{array}{c}\text { Very High } \\
5\end{array}$ \\
\hline GEOMORPHOLOGY & $\begin{array}{l}\text { Rocky cliffed } \\
\text { coasts, Fjords }\end{array}$ & $\begin{array}{l}\text { Medium } \\
\text { cliffs, } \\
\text { Indented } \\
\text { coasts }\end{array}$ & $\begin{array}{l}\text { Low cliffs, } \\
\text { Glacial drift, } \\
\text { Alluvial } \\
\text { plains }\end{array}$ & $\begin{array}{l}\text { Cobble } \\
\text { Beaches, } \\
\text { Estuary, } \\
\text { Lagoon }\end{array}$ & $\begin{array}{c}\text { Barrier beaches, } \\
\text { Sand beaches, Salt } \\
\text { marsh, Mud flats, } \\
\text { Deltas, Mangrove, } \\
\text { Coral reefs }\end{array}$ \\
\hline $\begin{array}{c}\text { SHORELINE } \\
\text { EROSION/ACCRETION } \\
(\mathrm{m} / \mathrm{yr})\end{array}$ & $>2.0$ & $1.0-2.0$ & $-1.0-1.0$ & $-2.0--1.0$ & $<-2.0$ \\
\hline COASTAL SLOPE (\%) & $>14.7$ & $10.9-14.65$ & $7.75-10.85$ & $4.6-7.7$ & $<4.55$ \\
\hline $\begin{array}{l}\text { RELATIVE SEA- } \\
\text { LEVEL CHANGE } \\
(\mathrm{mm} / \mathrm{yr})\end{array}$ & $<1.8$ & $1.8-2.5$ & $2.5-3.0$ & $3.0-3.4$ & $>3.4$ \\
\hline $\begin{array}{c}\text { MEAN WAVE HEIGHT } \\
(\mathrm{m})\end{array}$ & $<1.1$ & $1.1-2.0$ & $2.0-2.25$ & $2.25-2.60$ & $>2.6$ \\
\hline $\begin{array}{l}\text { MEAN TIDE RANGE } \\
(\mathrm{m})\end{array}$ & $>6.0$ & $4.0-6.0$ & $2.0-4.0$ & $1.0-2.0$ & $<1.0$ \\
\hline
\end{tabular}




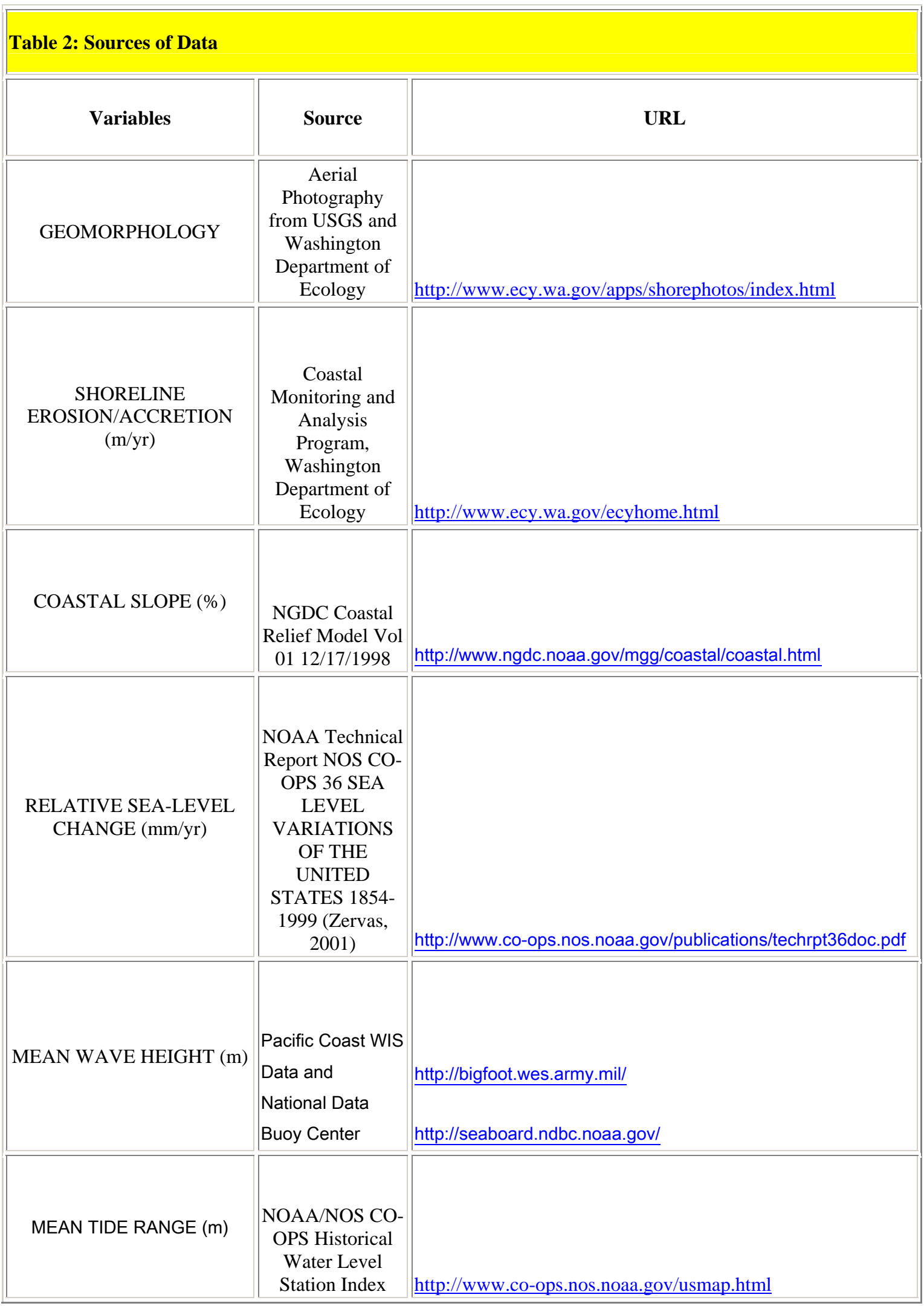

